\title{
Epeirogenic uplift above a detached slab in northern Central America
}

\author{
Robert D. Rogers Department of Geological Sciences and Institute for Geophysics, University of Texas, 4412 Spicewood \\ Springs Road, Building 600, Austin, Texas 78759-8500, USA \\ Hrafnkell Kárason ] Department of Earth, Atmospheric, and Planetary Sciences, Massachusetts Institute of \\ Robert D. van der Hilst $」$ Technology, 77 Massachusetts Avenue, 54-918, Cambridge, Massachusetts 02139, USA
}

\begin{abstract}
P-wave tomographic images reveal that the northern Central America highlands east of the modern volcanic arc overlie a detached slab. Hypsometric analysis of the highlands in Honduras demonstrates that the region is a dissected plateau that is disrupted by normal faults near the North American-Caribbean plate margin. The dissected Central American plateau contains a network of superimposed rivers with meanders cut into bedrock; such a geomorphic character indicates that the regional uplift occurred in the absence of tilting. We propose that the epeirogenic uplift of northern Central America is the buoyant upper-plate response to the influx of mantle asthenosphere following the breakoff and sinking of the slab.
\end{abstract}

Keywords: uplift, slab break-off, Central America, entrenched meanders, tomography.

\section{INTRODUCTION}

The origin of anomalous topographic relief distal from plate margins remains an unresolved geomorphic and tectonic issue in many regions. Theories for relief developmentincluding removal of mantle lithosphere (Bird, 1979; Platt and England, 1994) and subductionrelated lithosphere deflection (Mitrovica et al., 1989) - are debated in part because it is difficult to directly observe mantle-related reliefbuilding processes. Slab detachment, however, can be imaged by seismic tomography, proving a means of observing the mantle underlying areas of anomalous relief. Uplift attributed to asthenospheric upwelling is an effect of slab detachment in the MediterraneanCarpathian region and is supported by thermomechanical modeling (Wortel and Spakman, 2000; van de Zedde and Wortel, 2001).

Behind the volcanic arc in northern Central America (Guatemala, Honduras, El Salvador, and Nicaragua), mountainous topography with elevations $>1 \mathrm{~km}$ extends $400 \mathrm{~km}$ from the plate margins. To investigate this anomalous topography, we combine analyses of surficial landscape data using digital elevation model (DEM) and satellite imagery (LANDSAT) to quantify the magnitude and extent of the uplift with P-wave tomographic images of the mantle underlying the region. Within the context of the regional geologic and tectonic setting, we propose that the northern Central American plateau east of the modern arc developed in response to mantle upwelling following slab detachment.

\section{TECTONIC SETTING OF NORTHERN CENTRAL AMERICA}

Subduction of the Cocos plate and its predecessor, the Farallon plate, beneath the North
American and Caribbean plates produced the Middle America Trench, the modern Central American arc, and earthquakes along the plates interface (Figs. 1A and 1B). Seafloor magnetic-anomaly data from the Cocos plate indicate that Neogene rates of convergence at the Middle America Trench have varied. Spreading on the southernmost Pacific-Cocos segment of the East Pacific Rise achieved full spreading rates of 180-210 mm/yr between 10 and $19 \mathrm{Ma}$ (Wilson, 1996) following breakup of the Farallon plate and the initiation of CocosNazca spreading at $23 \mathrm{Ma}$ (Barckhausen et al., 2001; Wilson and Hey, 1995). The identified anomalies and symmetrical, but unidentified, post-10 Ma East Pacific Rise anomalies support the interpretation of a fixed position of the southernmost Pacific-Cocos segment of the East Pacific Rise. With the Caribbean plate immobile relative to the hotspot reference frame since 38 Ma (Müller et al., 1999), the position of the Middle America Trench has likewise been stable. Therefore, variable CocosPacific spreading rates require that convergence at the Middle America Trench increased between 10 and 19 Ma.

Northern Central America straddles the North American-Caribbean strike-slip plate margin, a tectonic scenario that produces intraplate deformation (Fig. 1A). South of the plate margin, rotation about the arcuate MotaguaPolochic fault system in Guatemala has led to the formation of about a dozen small rifts of late Miocene to Holocene age (GuzmanSpeziale, 2001; Burkart and Self, 1985; Fig. 2 ), whereas north of the plate margin, the displacement is taken up by post-middle Miocene shortening (Guzman-Speziale and Meneses-Rocha, 2000).

\section{MANTLE TOMOGRAPHY BENEATH CENTRAL AMERICA}

New P-wave tomographic images of the Middle America Trench margin and beneath northern Central America to the depth of 1000 $\mathrm{km}$ reveal a $300-\mathrm{km}$-wide gap in the subducted slab directly beneath the uplifted highlands (Fig. 1B). The gap parallels the Middle America Trench from the Tehuantepec Ridge to the Cocos-Nazca-Pacific triple junction trace (Fig. 1A). Tomographic images in cross section of the mantle beneath northern Central America show a complex, three-part geometry to the subducted Cocos slab (Fig. 1B). The upper part of the slab, which is poorly defined in the images, represents lithosphere subducted since $3.8 \mathrm{Ma}$ - if the present-day convergence rate $(7.5 \mathrm{~cm} / \mathrm{yr})$ and slab geometry are assumedand corresponds to the slab known from study of Wadati-Benioff zone earthquakes along the Middle America Trench (Burbach et al., 1984) (Fig. 1B). Beneath the high-velocity, seismically active slab is an area of mantle velocity interpreted as a 300-km-long gap in the currently subducting slab. A slab (lower slab, Fig. 1B) dipping eastward is present at depths of $500-1000 \mathrm{~km}$ in the mantle.

If the lower part of the slab broke off near the trench (50 km downdip slab distance) and if slab geometry and convergence rate were unaffected by the break, the minimum possible age for slab detachment is somewhat younger than $3.8 \mathrm{Ma}$. However, slab detachment along $\sim 50 \%$ of the convergent margin of the Cocos plate would presumably lessen slab-pull forces and slow convergence at the Middle America Trench; therefore, the lower slab broke off prior to $3.8 \mathrm{Ma}$.

\section{CENTRAL AMERICAN PLATEAU CHARACTER AND EXTENT}

The Central American plateau directly overlies the detached slab (Fig. 1B) and extends from east of the modern volcanic arc to the Caribbean Sea and includes the region of deformation of the North American-Caribbean plate margin. To illustrate its plateau-like character, we examine the hypsometry within catchments contained within three subregions of the plateau in Honduras at increasing distances from the plate margin by using data from the global $30 \mathrm{~s}$ GTOPO30 DEM (Fig. $3 \mathrm{~A})$. These regions are (1) the active fault- 
A
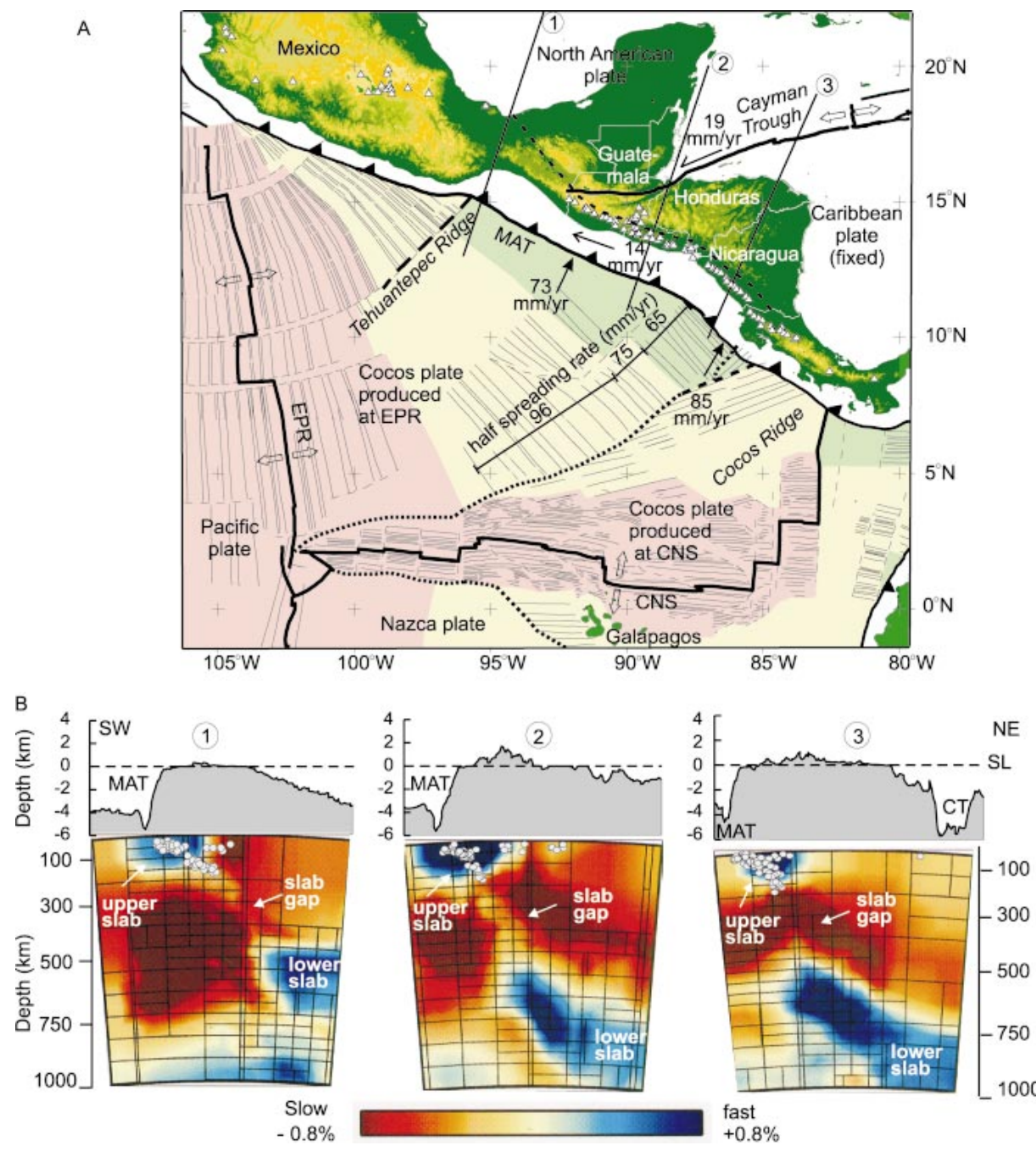

Figure 1. A: Setting of northern Central America showing plates, Cocos crust produced at East Pacific Rise (EPR) and Cocos-Nazca spreading center (CNS), triple-junction trace (heavy dots), volcanoes (open triangles), Middle America Trench (MAT), western edge of detached slab (dashed line), and rates of relative plate motion (DeMets et al., 2000; DeMets, 2001). East Pacific Rise half-spreading rates are from Wilson (1996) and Barckhausen et al. (2001). Ocean crust age: 0-10 Ma (pink), 10-20 Ma (yellow), older than $20 \mathrm{Ma}$ (green). Lines 1,2 , and 3 are locations of topographic and tomographic profiles in B. B: Upper-topography and bathymetry. Lower-tomographic profiles from global mantle tomographic model of Kárason and van der Hilst (2000), showing Cocos slab detached below northern Central America, upper Cocos slab continuous with subducted plate at Middle America Trench, and slab gap between 200 and $500 \mathrm{~km}$. Color indicates anomalies in seismic wave speed as $\pm 0.8 \%$ deviation from average mantle velocities. Blue colors indicate colder, subducted slab material of Cocos plate. Circles are earthquake hypocenters. Grid sizes on profiles correspond to quantity of ray-path data within that cell of model; smaller boxes indicate regions of increased data density. CT-Cayman Trough; SL-sea level.

bounded horst and graben province of western Honduras, (2) a central tectonically stable province containing erosion surfaces between 800 and $1000 \mathrm{~m}$ and bounded to the north by an active zone of strike-slip faulting, and (3) the heavily dissected mountains of eastern Honduras with few erosion surfaces. The western province contains Miocene ignimbrite strata, Cretaceous carbonate and clastic strata, and a basement of schist and gneiss (Wely, 1980). The central province contains mostly folded Cretaceous strata and metamorphic rocks, while metamorphic rocks are prevalent in the eastern province. Precipitation is at a the three subregions (Fig. 3B). Cumulative hypsometry is the progressive summation of the differential hypsometry. The cumulative hypsometry of the central province (Fig. 3B) reveals that $50 \%$ of the region is concentrated between 800 and $1100 \mathrm{~m}$. The central province represents the core of a moderately dissected plateau. Lower precipitation in this landlocked area contributes to the preservation of the plateau. In the western, rifted province, the elevation is more variable, although the mean elevation is approximately the same as in the central province (Fig. 3B). We attribute the variability of elevation values in the west to disruption of the plateau by rifting proximal to the plate margin. In the eastern province, the mean elevation is lower, and the differential hypsometry is skewed to the lower elevations. Higher precipitation has resulted in greater denudation of the plateau in the eastern area.

The type and extent of the uplift are recorded in the deeply entrenched rivers of the Central American plateau. These rivers contain low-gradient reaches with high sinuosity, as shown by the Rio Patuca in eastern Honduras (Fig. 4). We interpret these reaches as superimposed fluvial meanders entrenched into bedrock during uplift. Entrenched meanders develop where meandering alluvial rivers are superimposed into bedrock during uplift in the absence of significant tilting (Gardner, 1975; Schumm et al., 1987). Therefore, the presence of entrenched meanders reflects nearvertical epeirogenic uplift, and the distribution of entrenched meanders documents the extent of the uplift.

The distribution of entrenched meanders was mapped in northern Central America from composite 1:100 000-scale LANDSAT images and 1:50000-scale topographic maps (Fig. 2). Entrenched meanders are found at elevations of $>300 \mathrm{~m}$ in all lithologies across northern Central America. The continuity of entrenched meanders increases with distance from the plate margins, achieving greatest density and continuity in the relatively resistant metamorphic rocks of eastern Honduras and northern Nicaragua (Fig. 2). Entrenched meanders decrease in abundance near the active volcanic arc of El Salvador and Nicaragua and near the Motagua-Polochic faults and the actively deforming north coast of Honduras. Although abundant in western Honduras, entrenched meanders are disrupted into shorter segments by the normal faults of the north-trending rift basins. We interpret the distribution of entrenched meanders as having resulted primarily from the epeirogenic uplift of northern Central America but also having been affected by faulting and volcanic overprinting near plate margins. 


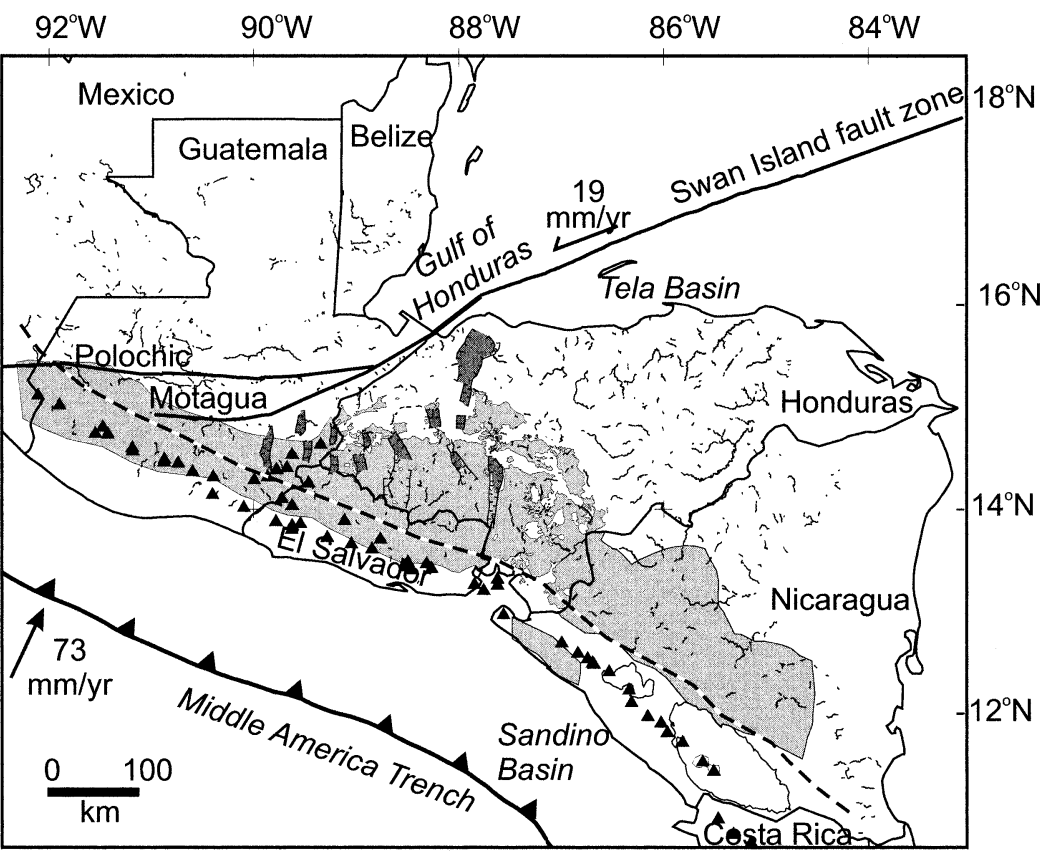

Figure 2. Northern Central America map shows extent of middle Miocene ignimbrite province (light gray) and north-striking late Miocene-Holocene grabens (dark gray) that cut ignimbrites. Superimposed river meanders (thin lines) incised into bedrock (including ignimbrites) during uplift of northern Central America were subsequently disrupted by north-striking rifts and by Quaternary arc volcanism (triangles). Dashed line is western edge of detached slab.

A
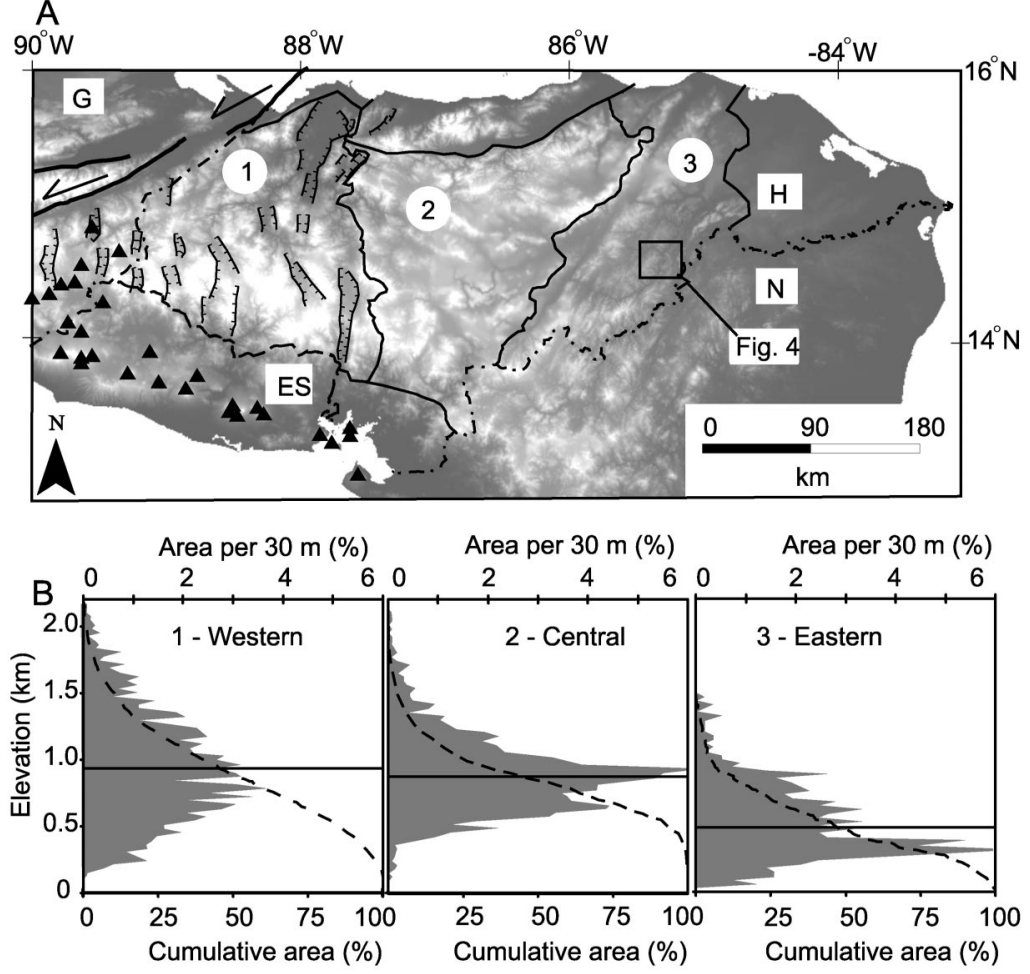

Figure 3. Comparative hypsometry of Honduras. A: Digital elevation model image displaying physiographic zones of Honduras $(\mathrm{H})$. Zone 1 is rifted proximal to plate margin, zone 2 is dry interior highlands, and zone 3 includes humid eastern mountains. Other abbreviations: N-Nicaragua; ES-EI Salvador; G-Guatemala. B: Hypsometry of zones 1, 2, and 3 of Honduras. Differential (shaded) and cumulative (dashed line) hypsometries have same vertical (elevation) axis but different horizontal axes. Solid line is mean elevation.

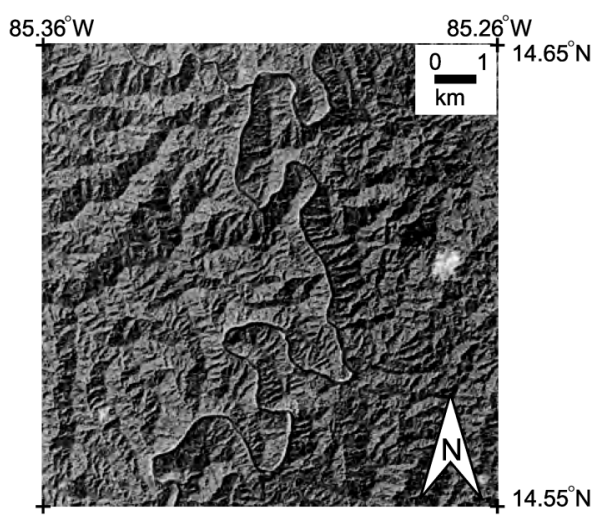

Figure 4. Superimposed bedrock meanders of Rio Patuca in Honduras.

\section{AGE OF UPLIFT OF THE CENTRAL AMERICAN PLATEAU}

The uplift is no older than the youngest rocks cut by the rivers' entrenched meanders. The youngest rocks that host entrenched meanders were deposited during the middle Miocene silicic ignimbrite flare-up event that blanketed the western third of northern Central America with as much as $2 \mathrm{~km}$ of strata (Williams and McBirney, 1969; Weyl, 1980; Fig. 2). The Ar/Ar geochronology of ash recovered from drilling in the Caribbean Sea dates the end of the 10-m.y.-long Central American ignimbrite flare-up at $10 \mathrm{Ma}$ (Sigurdsson et al., 2000), which agrees with published ages from the Coyol Group strata in Nicaragua (Ehrenborg, 1996). Williams and McBirney (1969) recognized that the thick ignimbrite strata blanketed low-relief terrain prior to uplift and that large-scale pyroclastic eruptions buried the earlier drainage network and allowed development of new meandering rivers that were subsequently entrenched.

The rifting that disrupts the entrenched meanders in western Honduras commenced after 10.5 Ma (Gordon and Muehlberger, 1994). Significant topography had developed by the latest Miocene, as shown by the valley-fill deposition of the 300-m-thick Gracias Formation in the rift valleys. These deposits contain abundant mammalian fauna of early Hemphillian age (9-6.7 Ma) (Olson and McGrew, 1941; Webb and Perrigo, 1984).

\section{DISCUSSION AND IMPLICATION FOR TECTONIC HISTORY}

We relate the uplift of the now-dissected plateau and the associated development of the network of entrenched meanders to a gap in the Cocos slab directly beneath the plateau (Fig 1B). Following slab detachment, hot asthenospheric mantle flows in to replace the cold, lower slab as it sinks into the mantle (Wortel and Spakman, 2000). Thermomechanical modeling of the slab-detachment process demonstrates large $\left(>500{ }^{\circ} \mathrm{C}\right)$ transitory heating of the base of the upper plate for several 


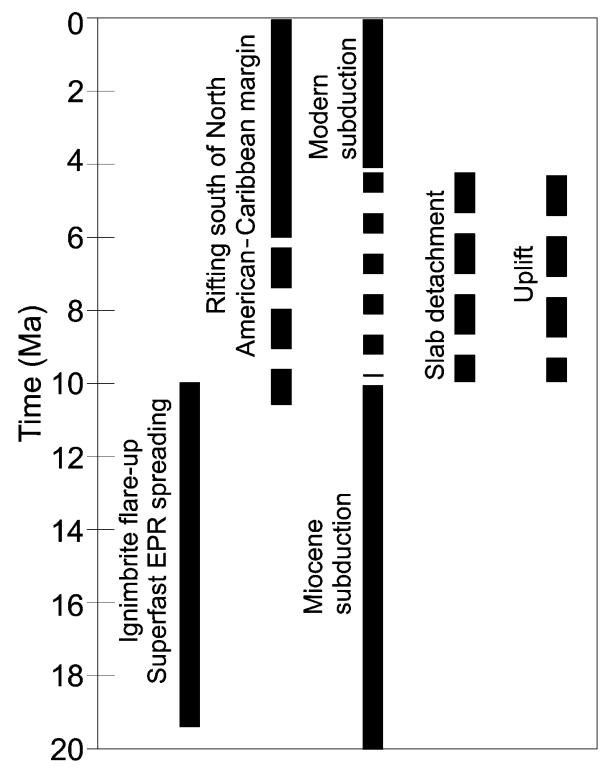

Figure 5. Timing relationships of Neogene events affecting northern Central America. EPR-East Pacific Rise.

million years following the slab detachment due to upwelling mantle (van der Zedde and Wortel, 2001). Asthenospheric upwelling can produce decompression-induced volcanism, and the geochemistry of the basaltic lavas from behind the volcanic front in Honduras and Guatemala is consistent with mantle upwelling (Walker et al., 2000). Slab detachment and the uplift of the Central American plateau occurred between the end of the subductionrelated ignimbrite flare-up at $10 \mathrm{Ma}$ and prior to $3.8 \mathrm{Ma}$, the time at which the tip of the Cocos slab was subducted (beginning of modern subduction; Fig. 5).

In collisional settings, slab detachment occurs as the force of slab pull near the trench is resisted by the attempted subduction of buoyant lithosphere that produces a tear in the downgoing slab (Wortel and Spakman, 2000). We suggest that this mechanism also occurred along the noncollisional Middle America Trench margin as a result of the decreasing age and increasing buoyancy of the incoming Cocos oceanic plate during the 19-10 Ma interval of superfast spreading along the southernmost Cocos-Pacific segment of the East Pacific Rise (Fig. 1). Although steady-state subduction at the Middle America Trench since 2.5 Ma has been inferred from the presence of cosmogenic isotopes in the modern arc lavas of Central America (Morris et al., 2002), our observations require highly variable subduction during the Neogene.

\section{ACKNOWLEDGMENTS}

Funding for R. Rogers was provided by the Petroleum Research Fund of the American Chemical Society (grant 33935-AC2 to P. Mann). We thank H. Sigurdsson, S. Carey, S. Schumm, U. Barckhausen, K. McIntosh, and P. Mann for discussions and Luca Ferrari and Tom Gardner for reviews. University of Texas Institute for Geophysics contribution 1603

\section{REFERENCES CITED}

Barckhausen, U., Ranaero, C., von Huene, R., Cande, S., and Roeser, H., 2001, Revised tectonic boundaries in the Cocos plate off Costa Rica: Implications for the segmentation of the convergent margin and for plate tectonic models: Journal of Geophysical Research, v. 106, p. 19207-19222.

Bird, P., 1979, Continental delamination and the Colorado Plateau: Journal of Geophysical Research, v. 84, p. 7561-7571.

Burbach, G., Frohlich, C., Pennington, W., and Matumoto, T., 1984, Seismicity and tectonics of the subducted Cocos plate: Journal of Geophysical Research, v. 89, p. 7719-7735.

Burkart, B., and Self, S., 1985, Extension and rotation of crustal blocks in northern Central America and effect on the volcanic arc: Geology, v. 13, p. 22-26.

DeMets, C., 2001, A new estimate for present-day Cocos-Caribbean plate motion: Implications for slip along the Central American volcanic arc: Geophysical Research Letters, v. 28, p. 4043-4046.

DeMets, C., Jansma, P., Mattioli, G., Dixon, T., Farina, F., Bilham, R., Calais, E., and Mann, P., 2000, GPS geodetic constraints on CaribbeanNorth America plate motion: Geophysical Research Letters, v. 27, p. 437-440.

Ehrenborg, J., 1996, A new stratigraphy for the Tertiary volcanic rocks of the Nicaraguan Highland: Geological Society of America Bulletin, v. 108 , p. $830-842$.

Gardner, T.W., 1975, The history of part of the Colorado River and its tributaries; an experimental study: Four Corners Geological Society Guidebook, v. 8, p. 87-95.

Gordon, M.B., and Muehlberger, W.R., 1994, Rotation of the Chortís block causes dextral slip on the Guayape fault: Tectonics, v. 13, p. 858-872.

Guzman-Speziale, M., 2001, Active seismic deformation in the grabens of northern Central America and its relationship to the relative motion of the North America-Caribbean plate boundary: Tectonophysics, v. 337, p. 39-51.

Guzman-Speziale, M., and Meneses-Rocha, J.J., 2000, The North America-Caribbean plate boundary west of the Motagua-Polochic fault system: A jog in southeastern Mexico: Journal of South American Earth Sciences, v. 13, p. $459-468$.

Instituto Geografico Nacional, 1996, Mapa Isohietico Anual (1966-1988): Guia para investigadores de Honduras: Tegucigalpa, Honduras, Instituto Geografico Nacional, p. 86-87.

Kárason, H., and van der Hilst, R.D., 2000, Constraints on mantle convection from seismic tomography, in Richards, M.R., et al., eds., The history and dynamics of global plate motion:
American Geophysical Union Geophysical Monograph 121, p. 277-288.

Mitrovica, X.J., Beaumont, C., and Jarvis, G.T., 1989, Tilting of continental interiors by the dynamical effects of subduction: Tectonics, v. 5 , p. 1079-1094.

Morris, J., Valentine, R., and Harrison, T., 2002, ${ }^{10} \mathrm{Be}$ imaging of sediment accretion and subduction along the northeast Japan and Costa Rica convergent margins: Geology, v. 30, p. 59-62.

Müller, D., Royer, J., Cande, S., Roest, W., and Maschenkov, S., 1999, New constraints on the Late Cretaceous/Tertiary plate tectonic evolution of the Caribbean, in Mann, P., ed., Caribbean basins: Amsterdam, Elsevier, p. 33-59.

Olson, E.C., and McGrew, P.O., 1941, Mammalian fauna from the Pliocene of Honduras: Geological Society of America Bulletin, v. 52, p. 1219-1244.

Platt, J.P., and England, P.C., 1994, Convective removal of lithosphere beneath mountain belts: Thermal and mechanical consequences: American Journal of Science, v. 294, p. 307-336.

Schumm, S., Mosley, P., and Weaver, W., 1987, Experimental fluvial geomorphology: New York, John Wiley and Sons, 413 p.

Sigurdsson, H., Kelley, S., Leckie, R., Carey, S., Bralower, T., and King, J., 2000, History of circum-Caribbean explosive volcanism: ${ }^{40} \mathrm{Ar} /$ ${ }^{39} \mathrm{Ar}$ dating of tephra layers, in Leckie, R., Sigurdsson, H., et al., Proceedings of the Ocean Drilling Program, Scientific results, Volume 165: College Station, Texas, Ocean Drilling Program, p. 299-314.

van de Zedde, D.M.A., and Wortel, M.J.R., 2001, Shallow slab detachment as a transient source of heat at midlithospheric depths: Tectonics, v. 20 , p. $868-882$

Walker, J.A., Patino, L.C., Cameron, B.I., and Carr, M.J., 2000, Petrologic insights provided by compositional transects across the Central American arc: Southeastern Guatemala and Honduras: Journal of Geophysical Research, v. 105 , p. $18949-18963$.

Webb, D.S., and Perrigo, S.C., 1984, Late Cenozoic vertebrates from Honduras and El Salvador: Journal of Vertebrate Paleontology, v. 4, p. 237-254.

Weyl, R., 1980, Geology of Central America (second edition): Berlin-Stuttgart, Gebrueder Borntraeger, $371 \mathrm{p}$.

Williams, H., and McBirney, A., 1969, Volcanic history of Honduras: University of California Publications in Geological Sciences, no. 85, $101 \mathrm{p}$.

Wilson, D., 1996, Fastest known spreading on the Miocene Cocos-Pacific plate boundary: Geophysical Research Letters, v. 23, p. 3003-3006

Wilson, D., and Hay, R., 1995, History of rift propagation and magnetization intensity for the Cocos-Nazca spreading center: Journal of Geophysical Research, v. 100, p. 10041-10056.

Wortel, R., and Spakman, W., 2000, Subduction and slab detachment in the Mediterranean-Carpathian region: Science, v. 290, p. 1910-1917.

Manuscript received April 17, 2002

Revised manuscript received July 19, 2002

Manuscript accepted July 23, 2002

Printed in USA 